\title{
VIBRASI PIKIRAN, KERUSAKAN OZON DAN BENCANA ALAM \\ SATU KESATUAN SISTEM KESADARAN KOSMOS: \\ Perspektif Teo-Kosmologis Post Metafisika
}

\author{
Oleh: \\ I Ketut Donder \\ Program Pascasarjana Institut Hindu Dharma Negeri Denpasar \\ IHDN Denpasar; E-mail: donderjvothi@gmail.com
}

\begin{abstract}
The Vedas have various concepts and theories about the creation of the universe. Vedic concepts are accepted by revelation, while Vedanta theories are created through contemplative research on macrocosms and microcosms. Creation theories in Vedanta, are: Manah theory or the theory of Virat, this theory states that the universe created from the mind of God. The second is the theory of Sabda, this theory states that the universe is created from the Voice of God, this theory is similar to the Big Bang theory. Other theory is the theory of Apah, this theory states that the universe came from water, and there are also many other theories. These theories seem to be compatible with modern scientific theories. This shows that the Vedic teachings have been an inspiration for scientists.

The Manah theory, sabda theory, Apah theory, and other theories are embedded by Hiranyagarbha theory. This theory states that the human mind, the mind of the cosmos, and the human mind, historically-theo-cosmologically, have a very close relationship. Hiranyagarbha theory that became the foundation of Hindu Cosmology describes that before the universe was created, there was an element of astaprakriti, the eight subtle elements without size (tan matra). The eight supernatural elements are buddhi (intellect), manas (mind), ahamkara (ego), akhasa (ether), vayu (air), teja (fire), apah (water), and pritivi (land), all within the warehouse. The universe is called Hiranyagarbha. Based on the Hiranyagarbha theory, the creation of the macrocosm begins with the consciousness of God, then moves the mind of God (Manas) connected to the manas that is on Hiranyagarbha. After the macrocosm, humans were created, then the mind of God, the mind of the cosmos, and the human mind have connectivity with each other. Therefore, do not ever think negative about anything.
\end{abstract}

Key Word: vibration, mind, ozone, disasters, system, consciousness, cosmos, metaphysics

\begin{abstract}
ABSTRAK
Veda memiliki berbagaikonsep dan teori tentang penciptaan alam semesta. Konsep-konsep Veda diterima berdasarkan wahyu, sedangkan teori-teori Vedanta diciptakan melalui riset kontemplatik terhadap makrokosmos dan mikrokosmos. Teori-teori penciptaan dalam Vedanta, antara lain: teori Manahatau teori Virat,yaitu teori yang menyatakan bahwa alam semesta tercipta dari Pikiran Tuhan. Kedua adalah teori Sabda, yaitu teori yang menyatakan bahwa bahwa alam semesta tercipta dari Suara Tuhan, teori ini mirip dengan teori Big Bang. Teori lainnya, teori Apah, yaitu teori yang menyatakan bahwa alam semesta berasal dari air, dan masih ada teori-teori lainnya. Teori-teori tersebut tampak memiliki kesesuaian dengan teori-teori sain modern. Hal ini menunjukkan bahwa ajaran Veda telah menjadi inspirasi bagi para ilmuwan.
\end{abstract}


Teori Manah, teori Sabda, dan teori Apah, dan teori lainnya dipayungi oleh teori Hiranyagarbha. Teori ini menyatakan bahwa pikiran manusia, pikiran kosmos, dan pikiran manusia secara historis-teokosmologismemiliki hubungan sangat erat. Teori Hiranyagarbha yang menjadi pondasi Kosmologi Hindu yang menguraikan bahwa sebelum alam semesta ini diciptakan, ia berada sebagai unsur astaprakriti, yaitu delapan unsur mahahalus tanpa ukuran (tanmatra). Delapan unsur mahahalus itu adalah budhi (intelek) manas(pikiran), ahamkara (ego), akhasa (ether), vayu (udara), teja (api), apah (air), dan pritivi (tanah), semuanya berada di dalam Gudang Semesta yang disebut Hiranyagarbha.

Berdasarkan teori Hiranyagarbha, penciptaan makrokosmos diawali oleh kesadaran Tuhan, kemudian menggerakkan pikiran Tuhan (Manas) yang terhubung dengan manas yang ada pada Hiranyagarbha. Setelah makrokosmos, manusia tercipta, maka pikiran Tuhan, pikiran kosmos, dan pikiran manusia memiliki koneksitas antara satu dengan lainnya. Karena itu jangan jangan pernah berpikir negatif kepada apapun.

KataKunci: vibrasi, pikiran, ozon, bencana, system, kesadaran, kosmos, metafisika

\section{PENDAHULUAN}

\section{I.1 Veda Pengetahuan Mahaluas Mengin- spirasi Para Ilmuwan}

$V e d a$ adalah pengetahuan mahaluas, karena itu Veda menjadi inspirasi para ilmuwan Timur dan Barat untuk menciptakan berbagai macam teori baik teori-teori sain maupun teori-teori sosial dan atau teori-teori humaniora. Terkait dengan teori penciptaan jagadraya atau alam semesta, $V e d a$ memiliki berbagai konsep dan teori tentang penciptaan alam semesta tersebut. Konsepkonsepnya diambildari Veda sebagai wahyu yang diterima secara kontempalik, sedangkan teoriteori penciptaan dalam Vedanta diciptakan melalui riset para jnanin, yogi, maharsi dengan metode komparatif kontemplatik terhadap makrokosmos dan mikrokosmos sebagai objek riset. Ada beberapa teori penciptaan dalam Vedanta yang dapat diuraikan pada artikel yang halamannya dibatasi, di antaranya: teori Manahatau teori Virat, yaitu teori yang menyatakan bahwa alam semesta beserta seluruh isinya tercipta dari Pikiran Tuhan (Manas). Teori kedua, adalah teori Sabda, yaitu teori yang menyatakan bahwa alam semesta tercipta dari Suara Tuhan (SabdaOm), teori ini mirip dengan teori Big Bang atau teori Ledakan Maha Dahsyat. Teori lainnya, adalah teori Apah, yaitu teori yang menyatakan bahwa alam semesta berasal dari Air Semesta (Apah) yang berada di dalam Hiranyagarbha, suatu Gudang Semesta Yang Mahabesar yang ada di dalam diri Tuhan Yang Mahaluas; Hiranyagarbha ini jugakerap dianalogikakan sebagai Kandungan Tuhan. Masih ada teori-teori lainyang tidak mungkin dapat diuraikan dalam tulisan ini yang dibatasi oleh jumlah halaman. Teori-teori tersebut tampak memiliki kesesuaian dengan teori-teori sain modern yang diciptakan oleh para saintis Barat. Hal tersebut menunjukkan bahwa ajaran Vedatelah memberi inspirasi bagi para ilmuwan sehingga mereka ingin membuktikan kebenaran-kebenaran Veda.Para pakar Veda baik Barat ataupun Timur menyatakan bahwa semakin saintifik para saintisatau ilmuwan, maka pemikiran dan hasilhasil risetnya akan semakin mendekati teoriteori Vedanta. Seorang kosmolog dan astronom yang sangat terkenal di dunia, yaitu Carl Sagan sebagaimana dikutip Donder (2007:10-12) dalam Kosmologi Hindu, menyatakan:

Profesor Carl Sagan, Professor of Astronomy and Space Sciences dari David Duncan dan Director Laboratory for Planetary Studies di Cornell University, mengatakan bahwa; "Agama Hindu adalah satu-satunya agama besar dunia yang membaktikan dirinya pada gagasan bahwa kosmos sendiri mengalami sejumlah besar peristiwa kelahiran dan kemati-an, tak terhitung jumlahnya. Ini merupakan satu-satunya agama di mana 
skala waktu di dalamnya sesuai dengan skala waktu kosmologi modern, dan itu tentunya tidak disengaja. Siklusnya bergerak dari sehari semalam seperti yang dialami seharihari sampai sehari semalam Brahma, yang panjangnya 8,64 miliar tahun, lebih panjang dari umur bumi atau matahari dan kira-kira setengah dari waktu sejak Dentuman Besar. Selain itu masih ada skala waktu yang lebih panjang lagi. Ada suatu dugaan mendalam dan menarik yang mengatakan bahwa alam semesta hanyalah impian dewa yang telah seratus tahun Brahma larut ke dalam tidur tanpa mimpi. Alam semesta larut dengan diri-Nya sampai setelah satu abad Brahma berikutnya ia bergerak, dan memulai lagi impian kosmik agung-Nya. Sementara itu, di tempat lain ada banyak alam semesta lain yang jumlahnya tak terhingga, masingmasing dengan dewa yang memimpikan impian kosmik agung-Nya. Gagasangagasan besar itu disaingi dengan gagasangagasan lain, mungkin lebih besar lagi. Dikatakan bahwa mungkin manusia bukan impian para dewa, tetapi dewalah impian umat manusia.

Ada banyak dewa di India, dan masingmasing dewa memiliki penjelmaan sendiri. Patung-patung perunggu Chola, yang dibuat sejak abad kesebelas, menampilkan beberapa macam penjelmaan dewa Shiwa. Dari semua ini, yang paling indah dan agung adalah gambaran penciptaan alam semesta yang berlangsung di setiap awal siklus kosmik, suatu tema yang dikenal dengan nama tarian kosmik Shiwa. Dewa ini yang dikenal dalam penjelmaan-Nya sebagai Nataraja atau Raja Penari yang memiliki empat buah lengan. Lengan atas kanan memegang tambur yang suaranya adalah suara penciptaan. Lengan atas kiri memegang lidah api, suatu peringatan bahwa alam semesta yang baru diciptakan ini, milyaran tahun lagi akan dihan-curkan. Dalam lagenda-lagenda ini terdapat benihbenih gagasan astronomi modern. --- jika materi yang ada lebih banyak dari yang kita lihat, tersembunyi di dalam lubang hitam atau di dalam gas panas tetapi tak kelihatan di antara galaksi-galaksi, maka alam semesta akan menghentikan sendiri pengembangannya dan mengikuti siklus berulang-ulang seperti yang berlangsung dalam kepercayaan di India. Terjadilah pengembangan diikuti dengan pengkerutan alam semesta demi alam semesta, suatu kosmos tanpa akhir. Jika kita hidup di dalam kosmos yang seperti ini, maka Dentuman Besar bukan penciptaan kosmos, tetapi hanyalah akhir dari siklus sebelumnya, penghancuran pen-jelmaan terakhir kosmos. Alam semesta berosilasi, kosmos tidak memiliki awal atau akhir (bhs Hindu menyatakan sebagai anadi ananta, pen.) kita berada di tengah-tengah siklus kematian dan kelahiran kembali berlangsung terusmenerus (Sagan, 1997: 337-339).

Berdasarkan uraian Carl Sagan, seorang kosmolog merangkap sebagai astronom Barat yang sangat terkenal di dunia, sebagaimana uraian di atas, maka hal itu membuktikan bahwa di dalam Veda tersedia berbagai ilmu pengetahuan yang belum banyak diungkap oleh para ilmuwan. Ketidakmampuan intelektual Hindu (khususnyapara intelektual Hindu Indonesia) disebabkan oleh dua faktor, yaitu faktor pertama, para intelektual Hindu Indonesia terlalu tergantung dan mengikuti sepenuhnya definisi agama menurut definisi yang ditetapkan oleh para teolog Agama Smitis dan filosuf Barat. Para teolog dan filsuf Barat mendefinisikan bahwa ajaran atau pernyataan agama yang telah diyakini tidak boleh salah. Oleh karena itu agama tidak boleh salah, sedangkan kebenaran sain itu dapat tumbang. Untuk menjaga agar kebenaran agama tidak tumbang, maka para teolog menciptakan dua ilmu yang dapat membela keyakinan agama, kedua ilmu itu adalah domatika dan apologetika. Para penganut paham definisi ini, maka ajaran selalu benar dan tidak boleh salah atau disalahkan oleh siapa saja. Hal ini mirip dengan aprorisme Brahma Sutra I.1.3 yang menyatakan sastra yonittvatartinya "pustaka suci adalah alat paling benar untuk sarana memahami Tuhan". Sutra ini dapat disebut sebagai sumber ilmu pengetahuan 
tentang Tuhan yang disebut "teologi". Tipologi pengetahuan ini tidak membenarkan menggunakan pikiran kritis atau pikiran radikal yang bersifat spekulasi filosofi. Bertolak belakang dengan tipologi teologi Brahma Sutra, Maharsi Vasistha sebagaimana dikutif oleh Prof. Radhakrishnan (2010:133) dalam bukunya sangat terkenal di seluruh dunia berjudul The Principlak Upanisads menyatakan:

Yukti-yuktam upādeyam vacanam balakād api anyat tṛnam iva tvājyam apy uktam padma janmanā

'The word even of child, if it is reasonable, should be accepted.

All else should be rejected even if it be said by the Creator '

(Walaupun kata-kata itu berasal dari mulut seorang bocah kecil, jika kata-katanya itu masuk akal, harus diterima, semua yang lainnya harus ditolak walaupun hal itu dinyatakan oleh Sang Pencipta).

Faktor kedua, para intelektual Hindu Indonesia dan ilmuwan Timur pada umumnya seperti dinyatakan oleh Penerbit Jala Sutra dalam Kata Pengatar buku karya Yasraf Amir Piliang yang berjudul Hiper Semiotika, menyatakan bahwa para ilmuwan Timur hanya sebagai pemahmah consumer teori-teori Barat dan tidak ada yang memproduksi teori. Kata pengantar ini mengandung maksud bahwa para ilmuwan Timur tidak memiliki nyali atau keberanian untuk berpapasan atau bertentangan dengan pendapat para pakar Barat. Ketidak-beranian ini muncul di dalam pikiran para intelektual Hindu disebabkan kurangnya mereka mendalami cara membangun ilmu melalui frameepistemology (bingkai tata kerja ilmu yang berkenaan denga nasal-usul, sifat, dan batas-batas pengetahuan.

Inilah dua faktor utama sebagai sumber ketidakberanian para intelektual Hindu untuk membangun atau menggali serta menggunakan teori-teori Hindu. Selain itu, faktor lainnya adalah bahwa para intelektual Hindu Indonesia atau ilmuwan Timur sangat jarang membaca membaca buku-buku karya para pakar sain India. Akibatnya, ilmu-ilmu Hindu seakan-akan tidak memberi kontribusi kepada duniailmu pengetahuan. Padahal menurut Datta dan Singh (2004) dalam bukunya berjudul History of Mathematics menyatakan bahwa Hindu (India) memiliki andil besar dalam membangun ilmu matematika. Matematika Veda diangkut oleh para penjajah India, yaitu Yunai, Arab, bangsa-bangsa lainnya serta yang terakhir adalah Inggris. Baik pada penjajahan Yunani, Arab, dan Inggris berbagai ilmu pengetahuan Hindu dibawa ke negeri penjajah. Bahkan pada era pemerintahan Inggris, sejarah Agama Hindu dimutilasi dengan tujuan untuk mengkonversi umat Hindu di India (Saraswati, 2007, The True History and The Religion of India; Donder, 2014 Kebenaran Sejarah Agama Hindu). Belajar dari catatan tersebut, maka para intelektual Hindu sudah pantas mandiri seperti istilah Bung Karno untuk membangun ilmu-ilmu Hindu.

\section{I.2 Teori Vedanta tentang Penciptaan}

Sesungguhnya sangat banyak teori-teori Hindu yang sangat popular digunakan di India dan juga di Barat. Namun karena para intelektual Hindu sangat jarang atau hamper tidak ada yang membaca teori-teori tersebut, maka para intelektual akademis Hindu atau para akademisi Hindu di Indonesia menganggap tidak ada teori dalam Hindu. Teori Manah, teori Sabda, dan teori Apah, dan teori lainnya dipayungi oleh teori Hiranyagarbha. Teori ini menyatakan bahwa pikiran manusia, pikiran kosmos, dan pikiran manusia secara historis-teo-kosmologismemiliki hubungan sangat erat. Teori Hiranyagarbha yang menjadi pondasi Kosmologi Hindu yang menguraikan bahwa sebelum alam semesta ini diciptakan, ia berada sebagai unsur astaprakriti, yaitu delapan unsur mahahalus tanpa ukuran (tanmatra). Delapan unsur mahahalus itu adalah budhi (intelek) manas(pikiran), ahamkara (ego), akhasa (ether), vayu (udara), teja (api), apah (air), dan pritivi (tanah), semuanya berada di dalam Gudang Semesta yang disebut Hiranyagarbha.

Berdasarkan teori Hiranyagarbha, penciptaan makrokosmos diawali oleh kesadaran Tuhan, 
kemudian menggerakkan pikiran Tuhan (Manas) yang terhubung dengan manas yang ada pada Hiranyagarbha. Setelah makrokosmos, manusia tercipta, maka pikiran Tuhan, pikiran kosmos, dan pikiran manusia memiliki koneksitas antara satu dengan lainnya. Karena itu jangan jangan pernah berpikir negatif kepada apapun.

Oleh sebab itu, aporisme Vedanta menyatakan sarva bhutam namaskaram keshavam pratigachchati; sarva bhuta tiraskaram keshavam pratigachchati artinya 'apapun yang kita hormati, maka penghormatan itu akan sampai kepada Tuhan'; sebaliknya 'apapun yang kita hina, maka penghinaan itu akan sampai kepada Tuhan. Oleh sebab itu, seyogyanya manusia tidak memancarkan gelombang pikiran negatif ke angkasa, karena pikiran negatif akan menjadi ozon spiritual negatif yang turut merusak lapisan ozon pada atmosfir bumi sebagai pelindung kehidupan di bumi ini.

\section{PEMBAHASAN}

\section{II.1 Teori Penciptaan Jagadraya sebagai Sebuah Sistem Semesta}

Seperti telah diuraikan di atas, bahwa sesungguhnya ada beberapa teori Vedanta yang membahas tentang penciptaan jadagraya. Pada artikel ini secara khusus membahas tentang teori Mahat atau teori Pikiran Semesta yang telah digunakan untuk mengkostruk Viratvidyāsebagaimana diuraikan dalam Kosmologi Hindu karya Donder (2007). Teori Mahat atau teori Pikiran Semesta, piiran menjadi salah satu unsur astaprakriti dan merupakan asas ketiga dalam astaprakriti tersebut yang mendorong Ego (Kehendak Kuat) Tuhan untuk menciptakan seluruh partikel semesta dalam Hiranyagarbha. Karena itu, pikiran manusia secara historis-teokosmologiVedadinyatakan memiliki hubungan yang sangat erat dengan Mahat atau Pikiran Semesta (Pikiran Tuhan). Sebab, secara historis kronologis bahwa pikiran manusia diresapi oleh Pikiran Tuhan atau Pikiran Semesta (Mahat) yang di Barat disebut Cosmic Consciousness. Timur maupun Barat mengakui bahwa ada Mahakesadaran yang menjaga setiap atom alam semesta, termasuk atom-atom sel otak manusia. Oleh karena itu kesadaran yang mengendalikan pikiran makrokosmos (cosmic mind) dan mikrokosmos (human mind) adalah sama yaitu God Consciousness (Kesadaran Tuhan), karena itu dalam teori penciptaan Veda, dinyatakan bahwa manusia (mikrokosmos) merupakan satu sistem rangkaian penciptaan makrokosmos. Kosmologi Hindu menguraikan bahwa sebelum alam semesta ini ada, ia berada sebagai unsur astaprakriti, yaitu delapan unsur mahahalus tanpa ukuran (tanmatra) yang berada di dalam Hiranyagarbha. Delapan unsur mahahalus itu adalah budhi (intelek) manas(pikiran), ahamkara (ego), akhasa (ether), vayu (udara), teja (api), apah (air), dan pritivi (tanah), semuanya berada dalam Gudang Semesta yang disebut Hiranyagarbha itu. Penciptaan alam semesta digerakan oleh pikiran Tuhan (Mahat) yang berhubungan dengan manas yang berada di dalam Hiranyagarbha.

Setelah makrokosmos tercipta, maka Tuhan menciptakan manusia dengan unsur yang sama dengan makrokosmos, sebagai manusia adalah miniature makrokosmosmos, sehingga manusia juga disebut mikrokosmos. Sehingga, di alam semesta ini menurut Veda ada tiga pikiran yang bersinergi, yaitu pikiran Tuhan, pikiran makrokosmos, dan pikiran manusia sebagai mikrokosmos. Tiga serangkai pikiran itu merupakan saling berhubungan, sehingga pikiran manusia memiliki efek kosmis, karena pikiran manusia terhubungan dengan pikiran Tuhan dan sekaligus juga terhubungan dengan pikiran makrokosmos. Karena itu, di Barat dikenal istilah corgitoergosum 'saya berpikir maka saya ada', dalam Hindu dikenal istilah yad bhavam tad bhavati 'apa yang diinginkan (dipikirkan), itulah jadinya'.

Uraian di atas menegaskan bahwa pikiran manusia memiliki pengaruh terhadap system kosmos, mengetahui hal itu maka seseorang mestinya tidak memvibrasikan pikiran negative terhadap apa saja. Sebab seluruh keberadaan di dunia ini merupakan satu jaringan sistem semesta yang saling mempengaruhi. Segala fenomena alam, bencana alam di dunia ini sebagai refleksi 
atas pikiran dan perbuata manusia sebagai subsistem kosmos.

\section{II.2 Fisika-Metafisika, Sakala-Niskala, Kesa- daran Kosmos dan Fisika Spiritual}

Terkait dengan pembahasan sub-bagian fisika-metafisika, sakala-niskala, kosmos dan kesadaran kosmos, dipandang sangat penting mengambil bagian-bagian penting dari buku karya Sirsikar (1996) berjudul Cosmic Laws As seen by (Physics - Metaphysisc). Karena sangat esensialnya buku ini untuk menambah pengetahuan umat manusia, sehinggaS. Vasant dari Paris juga memberikan catatan atau komentar penting terhadap buku ini. Vasant menguraikan: "Cosmic Laws insist that modern physicists will have to transcend the physical dimension to understand the behavior of an Atom, to measure the mental energy which is lighter and faster than Einstein's light and time. Cosmic Laws throw light on metaphysical laws in refrence to modern laws of physic, and other cosmological science".

Poin-poin penting tulisan Sirsikar (1996) terkait dengan artikel ini tidak diterjemahkan untuk menghindari para pengutip berikutnya hanya menggunakan terjemahannya saja. Halhal penting tentang uraian Sirsikar (1996) yang dibutuhkan terkait dengan adalah sbb:

Our uviverse with million thousand galaxies and billion thousand stars and trillion thousand planets us but a finite universe. All that is finite has a beginning and end. Mega universe of which our oniverse is by a part is beginningless endless. Many universes are being born and many are dying, many are in their infancy, many are young.... Smooth, continuous replacement is going on. As such this mega universe game can be called eternal. When metaphysics approves of the big bang then we owe and answer to Russians. That answer is, our universe is like a unit of planet in the mega universe system galaxies which are not moving directly from each other and their having side way velocity may be under extra-universal gravitational forces. Thus, this argument need not cancel big bang at the time of our universe.
Scripture, esoteric record, and my master Sri Ramachandraji Maharah of Shaha-jahapur - the great yogi of unprecedental heights calls it i.e. a big bang as kshobha/great upheaval/a stir. Now this big bang has not taken the way physicsts imagine. They imagine the sudent explosion of energies. Yes, that thud also has taken place but when the physical process manifested on the plane of fire element.Metaphysically even the physical process starts with paraperceptional stage (from out today's perceptions). It starts with Akhashic manifestation; then vayu emerged from akhashya, then out of air the fire was born. So, it is quite likely that 2.5 thousand million years before the firy explosion might have taken place. In many ways e.g., human evolution, star/planets birth process, metaphysics differs from the physicists or scientists but here we are together. Timings agree with each other should I congratulated Stephan? Or metaphysics? (Stephens big bang takes place 10 to 20 thousand million years before. Metaphysically outer limit is 25 thousand million. The difference is not much).

It would be interesting to see what metaphysics speaks if the big Crunch. Metaphysical versions are for the initiates, yet they are direct, simple, poetic, and full of higher truths. Secrete Doctirine reveals, "Fohat-i.e. the creative power-Brahma exhales and universe exapands: Brahma inhales and universe contracts.'From metaphysical angel the physical universe has transformed itself into Astral Univers. When galaxies were retracing towards the centre their movements where cyclelic, spiral. Apparent cause of this collision may be local, inter-planetary, or inter stellar but the result is same, the physical pancha Mahabhutas get meged into Akashya, and in due couse of time Akashya gets merge into its parent Guna - tamoguna. Tamoguna is at astral level now.In metaphysics Sigularity has different connotation. Itis a micro cell, or a micro egg inwhich all th experiennce of earlier life-span are stored $\mathrm{n}$ essence, in seed form. Here the essence is stored in form of impressions/ experiences/ dormant memory ....with the help of three gunas, which fall into a state of equilibrium ... causing passivity like space. 
Metaphysical singularity is a state of passivity whih is percivable only by the Divine cosmic creative intelligece. To have a clear concept of this issue it is better to know the story of creation which is higly meaningful. The story says that Brahma entered into the egg, and egg came to life with radiating golden colour. Actually, Brahma with his thought force made the centre core of the egg tunned up eith mega universe centre from which the $O M$ current / energy was radiating. With the entery of OM.OmkaraBrahma egg came to life. $O m$ is the perfect three-fold eternal creative power, it is called in Vedas, Omkar is the infinite three-fold frequency band. Brahma is the carrter frequency, Vishnu is the information / infinite wisdom, Mahesha is the time, the modulating device. This is a metaphysical clue why at a particular time a particular event i.e., information is released at a particular place.

To be brief, on vibration entred the passive cell. Impressions in the cell got polarized. Thus, three Gunas ' equilibrium is disturbed. Polarization gave birth on duality. Positive end come to be known as sat or intelligent purusha.Negative end is known as Prakriti. Inter-action of these two is RajoGuna. With polarization the universe is born in foetus. Life span of the universe, according to metaphysics consists of pre-natal stages and also post death stages. These stages are broadly seven, they are clled rounds, first three - primordial, ethereal, astral rounds are prenatal (Srisikar, 1996:8-14).

Selanjutnya, bagian penting lainnya dari tulisan Srisikar (1996) ini adalah pada bagian uraian tentang Anu: And Three Dimensions, Srisikar menguraikan:

Today Physical Science have done wonderfull progress, yet scientists are realizing more than ever, the inadequacy of physical laws of explain the behavior of energy in coherent way. Just few years before transmutation of an Atom was considered possible only through tremendous nuclear energy. Today know that in the presence of bio-chemical energy potassium with ion of Hydrogen can be transmuted into calcium. Very soon all physical sciences would accept metaphysical expalanations, because in search of truth they will have to transcend physical dimension. They would understand that metaphysic is the only way to look at life in integral wholesomeness.

$A n u$ is different in constitution, behavior than physicist's Atom. Modern physics has taught us to look at the world from organic, inorganic angles. Inorganic substances consist of elements like gold, silver, lead, carbon, oxygen, hydrogen etc. Atom has neoutron, proton, electron with sub-atomic particles like quarks, photons etc. Metaphysics looks at the whole issue in different fashion, with totally different concept. In metaphysics there is no element in modern sence. There exists one essence/one energy/at the root of all manifestation. The energy has two faces or sides. At unmanifested end we call this energy as absolute. Nobody can comment on it. Metaphysics does not touch it. It seems infinite, all pervarding, eternal. Seers could not describe it what they said about it is, not this ... not this (not known). At manifestation level this energy is three-fold. All three-fold are inseperable. If one is seen then the other two have to be there. The folds are abstract ... space, time and motion are the name metaphysics has give to them. Each fold is associated with its essence. Essences are known as gunas, space is associated with Satva guna. Motion with Rajo gunaand time with Tamo guna. Again, these gunas are inseperable, if one is there then other two ought to be present. When we call Satva guna, as "Satva" it means it is premordinantly present in a given frame of refresence, while other two are dormant.

$A n u$ is the smallest unit of this energy, therefore it must have (1) immutable spark of Divinity and, (2) Satva, Rajo, Tamo guna in its constitution. Thus, Anu is the differentiated smallest unit having both the facets of root/ Absolute/all pervading/Primordial Energy. The two facets/constituents of Anu have seven subdivisions, these sub-divisions are known as Principle of Anu.

1. Divine spark, i.e., (differentiated spark of that immutable energy of which metaphysics knows nothing, it is soul). 
2. Ego (Awareness of one's seperable existance/ individuality)

3. Mind (the facukty of feel will, know)

4. Kama (inbuilt desire to create/pro-create)

5. Prana (vital energy, Bio-energy. It is a carrier of desire)

6. Lingga body (the etheric counterpart of the physical body)

7. Physical body (it is made up of five physical elements namely; a. akashya (ether), b. vayu (air), c. agni/teja (fire), d. apah (water), and e. prthivi (earth).

Metaphysics does not speak about the first principle-soul, except that it is there in Anu. For the rest of the six principles it says, ego and mind are Satva guna products. Kama and prana are predominantly Rajo gunaproducts. Lingga and physical body are Tamo guna products. Thus, we see that soul and three gunas are constituents of Anu. Thus, we see that except for the absolute, there is no element in metaphysics. All are compounds. $A n u$ is smallest unit of that energy three-fold energy. Each $A n u$ is unique, in weight density, texture combination so each $A n u$ is "Isotope". According to gold Anu it can describe that all gold Anus are unique but difference is so negligible from our perspective that they are classed as gold Anus of gold metal. Concept of isotopes (in refernce to physicst's Atom) is not applicable to metaphysical concept of Anu. This answer the Random Theory in physics. Metaphysics says those water molecules which have Rajo guna more react first. Molucules having Tamo guna react last. Whatever exists must be made of Anus. All planes are made of Anus, then the question arises, how are the laws different on different dimensions? If evolution of Anu is known the the answer is known. Let us start from physical plane (Srisikar, 1996:23-25).

Mineral of Anus are seeming - inert, devoid of intelligence or consciousness, mobility. Mineral of $\mathbf{A n u}$ has all seven principles from soul, mind to physical body, then why and how this Anu is inert? The answer is, all upper five principles, namely soul ego, mind, kama, prana, are fully dormant. Only Lingga body i.e., etheric counterpart, and physical body in mineral form are fully manifested. Evolution of Anu means unfolding of pranic faculty in it. How does it unfold? When? Strain, stress, shocks, heat, cold, pressure have varied effect on varied kingdoms, namely mineral, vegetable, animal, human kingdoms. Evolution on any dimension or in any kingdom needs Tapa. Tapa is a Sanskrit word which means penance, heat. In mineral kingdom for evolving further mineral $A n u$ needs physical heat or bio-chemical heat, when in excited state Anu can not pass out its energy, then it splits. This transit is very important mile stone in its evolution. In this transit Anu's physical body is split-dropped, and the pranic faculty unfolds. At this juncture Anu is a pranic entity without physical body. This pranic entity needs body from mineral kingdom. As a simple cell this entity starts its life in any of the three kingdoms namely vegetable, animal, and human.

A simple cell is an organic body having pranic entity and mineral body. As a living entity on physical plane the cell breaths. It moves, it feels/it reacts, the pranic entity incarnates many a times developing its capacity of feeling/ reacting/adjusting. When the lessons are learnt adequately, it is upgraded into vegetable kingdom as an entity presiding over - first simpler and then complex vegetable spicies. Here the entity no longer presides over a simple cell, but on complex of varied different cells of a bush or a creeper or a fern or a tree. Thus Anu - entity is in vegetable kingdom. Kama, mind, ego faculties are dormant in vegetable kingdom. Yet it has a touch of instinctive lower kama faculty. It has periods of sleep and awakening. It does not will but it reacts to good/bad feeling. It moves partially, it procreates a - sexually. Even in vegetable kingdom each entity can be classified as sattvic, rajasic, or tamasic. They are best organic energies for distant communication. Just as iota or bio-chemical energy can bring abound transmutation of an element, similarly small but unhurt plants/grains can be used for long-distance tele communication. In India seers knew this secret many years ago. Tulsi leaves/flower bunch can transmit sattvic 
message /information to astral as well as causal plane beings. Durva can transmit rajoguna predominant information to other planes. While Bel leaves are perfect antenas to transmit tamo guna information to these etheric regions, which are parts of existence in neat vicinity of the earth.

Any how to come back to evolution of an Anu, metaphysics says: After staying in vegetable kingdom for years the pranic entity is upgraded as animal entity. In animal kingdom the kama faculty gets unfolded. Kama means lower mind, it feels, knows, wills instinctively, Satvic pranic entities are attracted to sattvic species like cow, dolphins. Rajo guna pranic entities are attracted to Rajasi species like dog, horse, etc. Tamo guna pranic entities are attracted to tamo guna species like lions, tigers, bears. Often the perceptional range of animals is far more than human range e.g., dog listens as silent whistle; dog, cats, cows, horses etc., can see astral plane beings, many of them telepathic. Crocodile can sense a danger to her eggs on the shore from miles away. It because of this extra perceptional faculty, that the ancients could read from their reactions the good or bad times in near future. In physical strength, in perceptional range animal can surpass humanbeings but still human kingdom is on the higher evolutionary grade because in human kingdom higher mind is unfolded. Higher mind means the capacity to feel, will, think logically about abstract ideas/concepts, with individual awareness.

In human kingdom the higher mind mind i.e., mind faculty gets unfolded. Man is the species which can conceive mind in its full essence. Ego is the in between passage. Sould i.e., differentiated Divine spark appears ego only due the touch of mind. At present human as a race has not developed his mental faculties in full. Clairvoyance, telepathy, and psychometry are few of basic mental faculties. Gods i.e., higher extra-terristral intelligence have full awakend mind. Thus, they have the power which lie within the domain of universal mind/ universal essence. These, so called Gods need not be called spiritual beings. Difference between the highly developed mental and spiritual beings is elusive but not uncertain.
Higher mental beings have a tendency to do all that is positive, beneficial, according to cosmic laws. Due to these tendencies they grow, they prosper, they know all the cosmic laws. But they lack one thing - total surrender to that immute Divine will. Hence, they can not transcend existence, which is product of positive and negative forces. This is the reason why genuine masters are higher in evolution than gods. Masters alone are spiritual beings, in real sense. Rest of the team ... e.i., Munis, Rishi, Angles, are executives doing the allotted cosmic work. Metaphysics says that when entity transenden mental faculty i.e., awareness of Ego it merges into Divine Spiritual root essence or energy (Srisikar, 1996:26-29).

Berdasarkan urian di atas dapat diketahui tingkat kesadaran bhuta (mahluk) bahkan kesadaran material. Manusia memiliki puncak kesadaran yang dapat mngetahui dirinya sebagai sesuatu yang tunggal dengan Pencipta dan dapat menyesuaikan dengan level kesadaran mahluk lainnya. Manusia memiliki kemampuan atau kesanggupan (stuff) yang melebihi dari kemampuan mahluk lainnya. Ketika manusia sampai pada pencapaian pengetahuan Raja Yoga, yaitu raja dari segala raja pengetahuan, ketika seseorang telah mencapai kesadaran yogi, ia akan mampu lebur dalam kesadaran kosmis dan mampu berkomunikasi dengan unsur panca tanmatra yang diresapi oleh kesadaran Tuhan. Itulah sebabnya panca tanmatra mampu diperintah untuk menjadi apapun oleh kehendak sang yogi, itulah yang disebut sebagai manusia kosmis. Srisikar menguraikan sebagai berikut:

That stuff is Astral. It is made up of pranaand kama(desire). It is made up of "Tanmatras". Sound, touch, sight, taste, and smell are called tanmatras. When we wake up, that stuff vanishes. Where has it gone? It has not gone any where, it is very much there, the only difference is our astral faculties became dormant when we woke up. The Astral plane is penetrating the physical. It is not etheric, which can be seen by Kirlian techniques. Ether i.e., Akasha is one of the pancha mahabhutas. Astral frequency is much higher than Akasha or ether. All of us have heard of electro-magnetic spectrum 
marked in terms of hertzs. Human being sees hears or perceives through senses in limited range, he is not aware of existence which lies below or above these frequency range. On electro magnetic spectrum we may see that this Astral frequency range is beyond physical perception range, but actually it is penetrating the physical range, it is interacting with physical range. Due to vital (prana) energy bio chemical process in out body is possible. Due to prana energy our sensations are transmitted to brain, and in consequence our body reacts. Prana in our body is carrier of sensations which appears as desires (why and how sensations become desires is an interesting process which we can not deal with here). Prana has accupied each and every cell of our body. Prana is carrier of kama/desires; thus,kama or Astral body resembales physical body, through it is seperable (Srisikar, 1996:30-31).

Membaca ringkasan poin-poin penting uraian Srisikar (1996) di atas dapat membuka wawasan pengetahuan kita tentang hubungan dunia material dan dunia spiritual. Walaupun demikian Srisikar masih ragu-ragu untuk menyatakan bahwa alam semesta beserta seluruh system galaksinya adalah badan material (1/4 wujud material) dari Tuhan sebagaimana dinyatakan dalam Upanisad; Atmā vā idam eka evāgra āsit artinya: 'jiwa sajalah sesungguhnya yang ada pada permulaannya' (Aitarea Upanisad I.1.1); sarva khalv idam Brahman artinya: 'segalanya adalah manifestasi dari Tuhan' (Chandogya Upanisad III.14.2); idam Brahman idam sarvam artinya: semuanya adalah perwujudan Tuhan' (Brhadaranyaka Upanisad II.5.14); esa ta atma sarvatarahartinya: 'jiwa yang satu itu yang meresapi segalanya' (Brhadaranyaka Upanisad III.4.1); sa eva saumya, idam agra āsīd ekam evādityam artinya: 'pada permulaannya, hanya ada satu wujud yang Esa ini (Chandogya Upanisad VI.2.1); Atmaivedam agra àsit purusavedhah artinya: 'pada permulaannya dunia ini adalah Atman atau Roh' (Brhadarnyaka Upanisad I.4.1).

Pernyataan-pernyataan Upanisad di atas selaras dengan pernyataan GeguritanSucitapupuh Sinom pada Jilid I Bab I Pupuh 31 berbunyi: Ne sakala lan niskala, atepang mangden mamesik, reh jati palinggan tunggal, Hyang Wisesa ngaraganin, da malasang di hati, tingkahe nimbakang unduk, kayane patut jalanang,kaniskala mangden pasti, mudra iku, tikasing parek ring Hyang. 'Yang nyata dan yang tidak nyata, disatukan agar menjadi satu, sebab sesungguhnya merupakan (tempat, sesuatu) yang tunggal, Yang Maha Kuasa yang menjiwai (meresapi), jangan sampai memisahkan (walaupun hanya) dalam hati, perilaku membahas masalah, perilaku yang baik (hendaknya) dilaksanakan, yang gaib agar diyakini secara pasti, itulah, perilaku seorang abdi Tuhan'

KESIMPULANNYA: bahwa sesungguhnya alam semesta beserta seluruh isinya adalah satu system semesta yang didasari oleh kesadaran Tuhan. Tuhan masuk meresapi seluruh atom alam semesta hingga ke inti atom alam semesta menjadi pengendali alam semesta dan mewujud menjadi Rtam (Hukum Alam).

\section{II.3 Ozon Gas Beracun Pelindung Kehidupan di Bumi dan Dosa Manusia atas Bumi}

Orang sering mendenar kata ozon, ozon, dan ozon, tetapi tidak banyak yang tahu, apa sesungguhnya ozon itu. Oleh sebab itu, manusia semestinya sangat penting mengetahui sebab konon jika lapisan ozon itu rusak maka bumi bisa kiamat, karena kerusakan ozon itu akan menyebabkan tidak adanya lagi yang menyaring radiasi matahari. Itu artinya bahwa rusaknya lapisan ozon akan membiarkan radiasi panas matahari akan langsung menerpa permukaan bumi, hal itu akan menyebabkan bumi makin panas, semua air di samudera akan menguap, selanjutnya bumi hangus terbakar. Itulah efek jika lapisan ozon rusak, rusaknya lapisan ozon disebabkan oleh gas-gas pulutan (pencemaran) yang disebabkan oleh pabrik-pabrik atau industri yang menggunakan listri dan terutama gas-gas hasil mesin pembakaran bahan bakar minyak. Jiwa mahluk hidup sangat tergantung pada ozon, karena itu sehingga ozon menjadi sesuatu yang amat sangat penting bagi kehidupan di bumi. Sumber website yang dapat percaya, yaitu: https:// id.wikipedia.org/wiki/Lapisan_ozon, diakses 25- 
01-2018 menguraikan secara gambelang tentang apa itu ozon. Oleh sebab itu, dalam artikel ini sangat penting menyajikan uraian tentang ozon itu secara utuh. Sumber website menguraikan:

Lapisan ozon adalah lapisan di atmosfer pada ketinggian $20-35 \mathrm{~km}$ di atas permukaan Bumi yang mengandung molekul-molekul ozon. Konsentrasi ozon di lapisan ini mencapai 10 ppm dan terbentuk akibat pengaruh sinar ultraviolet Matahari terhadap molekul-molekul oksigen. Lapisanozon adalah lapisan di atmofer pada ketinggian $20-35 \mathrm{~km}$ di atas permukaan Bumi yang mengandung molekul-molekul ozon. Konsentrasi ozon di lapisan ini mencapai 10 ppm dan terbentuk akibat pengaruh sinar utraviolet Matahari terhadap molekul-molekul oksigen. Peristiwa ini telah terjadi sejak berjuta-juta tahun yang lalu, tetapi campuran molekul-molekul nitrogen yang muncul di atmosfer menjaga konsentrasi ozon relatif stabil.

Lapisan ozon ditemukan pada tahun 1913 oleh fisikawan Prancis Charles Fabry dan Henri Buisson. Pengukuran sinar matahari menunjukkan bahwa radiasi yang dikirim keluar dari permukaannya dan mencapai tanah di Bumi biasanya sesuai dengan spektrum benda hitam dengan suhu di kisaran 5,500-6.000 K (5,277 sampai $5,727^{\circ} \mathrm{C}$ ), kecuali bahwa tidak ada radiasi di bawah panjang gelombang sekitar $310 \mathrm{~nm}$ pada akhir spektrum ultraviolet. Disimpulkan bahwa radiasi yang hilang diserap oleh sesuatu di atmosfer. Akhirnya spektrum radiasi yang hilang hanya cocok untuk satu kimiawi, ozon. Sifat-sifatnya dieksplorasi secara rinci oleh ahli meteorologi Inggris G. M. B. Dobson, yang mengembangkan spektrofotometer sederhana (yang dapat digunakan untuk mengukur ozon stratosfer dari tanah. Antara 1928 dan 1958, Dobson mendirikan jaringan stasiun pemantauan ozon di seluruh dunia, yang terus beroperasi sampai hari ini. "Satuan Dobson", ukuran yang mudah digunakan dari bagian teratas ozon, dinamai untuk menghormatinya.

Lapisan ozon menyerap 97 sampai 99 persen frekuensi menengah sinar ultraviolet Matahari (panjang gelombang dari sekitar $200 \mathrm{~nm}$ hingga $315 \mathrm{~nm}$ ), yang sebaliknya berpotensi merusak kehidupan yang terpapar di dekat permukaan. Majelis Umum Perserikatan Bangsa-Bangsa telah menunjuk 16 September sebagai Hari Internasional untuk Pelestarian Lapisan Ozon.

Ozon adalah gas beracun sehingga bila berada dekat permukaan tanah akan berbahaya bila terhisap dan dapat merusak paru-paru. Sebaliknya, lapisan ozon di atmosfer melindungi kehidupan di Bumi karena ia melindunginya dari radiasi sinar ultraviolet yang dapat menyebabkan kanker. Oleh karena itu, para ilmuwan sangat khawatir ketika mereka menemukan bahwa bahan kimia klorofluorokarbon (CFC) yang biasa digunakan sebagai media pendingin dan gas pendorong spray aerosol, memberikan ancaman terhadap lapisan ini. Bila dilepas ke atmosfer, zat yang mengandung klorin ini akan dipecah oleh sinar Matahari yang menyebabkan klorin dapat bereaksi dan menghancurkan molekulmolekul ozon. Setiap satu molekul CFC mampu menghancurkan hingga 100.000 molekul ozon. Oleh karena itu, penggunaan CFC dalam aerosol dilarang di Amerika Serikat dan negara-negara lain di dunia. Bahan-bahan kimia lain seperti bromin halokarbon, dan juga nitrogenoksida dari pupuk, juga dapat menyerang lapisan ozon.

Menipisnya lapisan ozon dalam atmosfer bagian atas diperkirakan menjadi penyebab meningkatnya penyakit kanker kulit dan katarak pada manusia, merusak tanaman pangan tertentu, memengaruhi plankton yang akan berakibat pada rantai makanan di laut, dan meningkatnya karbon dioksida akibat berkurangnya tanaman dan plankton. Sebaliknya, terlalu banyak ozon di bagian bawah atmosfer membantu terjadinya kabut campur asap, yang berkaitan dengan iritasi saluran pernapasan dan penyakit pernapasan akut bagi mereka yang menderita masalah kardiopulmoner.

Pada awal tahun 1980-an, para peneliti yang bekerja di Antartika mendeteksi hilangnya ozon secara periodik di atas benua tersebut. Keadaan yang dinamakan lubang ozon (suatu area ozon tipis pada lapisan ozon) ini, terbentuk saat musim semi di Antartika dan berlanjut selama beberapa bulan sebelum menebal kembali. Studi-studi yang dilakukan dengan balon pada ketinggian tinggi 
dan satelit-satelit cuaca menunjukkan bahwa persentase ozon secara keseluruhan di Antartika sebenarnya terus menurun. Penerbanganpenerbangan yang dilakukan untuk meneliti hal ini juga memberikan hasil yang sama.

Pada tahun 1987, ditandatangani Protokol Montreal, suatu perjanjian untuk perlindungan terhadap lapisan ozon. Protokol ini kemudian diratifikasi oleh 36 negara termasuk Amerika Serikat. Pelarangan total terhadap penggunaan CFC sejak 1990 diusulkan oleh Komunitas Eropa (sekarang Uni Eropa) pada tahun 1989, yang juga disetujui oleh Presiden AS Geogre Bush. Pada Desember 1995, lebih dari 100 negara setuju untuk secara bertahap menghentikan produksi pestisida metil bromida di negara-negara maju. Bahan ini diperkirakan dapat menyebabkan pengurangan lapisan ozon hingga 15 persen pada tahun 2000 . CFC tidak diproduksi lagi di negara maju pada akhir tahun 1995 dan dihentikan secara bertahap di negara berkembang hingga tahun 2010. Hidroklorofluorokarbon atau HCFC, yang lebih sedikit menyebabkan kerusakan lapisan ozon bila dibandingkan CFC, digunakan sementara sebagai pengganti CFC, hingga 2020 pada negara maju dan 2016 di negara berkembang.

Untuk memonitor berkurangnya ozon secara global, pada tahun 1991, National Aeronautics and Space Administration(NASA) meluncurkan Satelit Peneliti Atmosfer. Satelit dengan berat 7 ton ini mengorbit pada ketinggian $600 \mathrm{~km}(372$ mil) untuk mengukur variasi ozon pada berbagai ketinggian dan menyediakan gambaran jelas pertama tentang kimiawi atmosfer di atas(https:// id.wikipedia.org/wiki/Lapisan_ozon, akses 25-012018).

Penjelasan tentang ozon secara komprehensih, seperti uraian di atassangat perlu dipahami oleh seluruh umat manusia, sebab, ozon ternyata menjadi kunci kehidupan di bumi ini. Kerusakan ozon menyebabkan lapisan ozon akan robek atau berlubang sehingga radiasi matahari akan langsung menerobos bumi dan berakibat suhu bumi naik semakin panas dan menyebabkan es kutub utara mencair semakin banyak hal itu menyebabkan permukaan air laut semakin naik, hal ini menyebabkan daratan akan semakin banyak terendam atau tenggelam oleh air laut. Jika ozon rusak berarti kehidupan juga akan rusak; hilangnya ozon berarti sama dengan hilangnya kehidupan; hilangnya kehidupan lain katanya adalah kematian. Oleh karena itu ozon identik dengan nyawa bumi. Para ilmuwan sudah mengetahui bahwa kerusakan ozon disebabkan oleh perilaku umat manusia.

Setiap umat manusia memiliki kontribusi dosa atas kerusakan ozon sesuai dengan tingkat kesejahteraannya. Donder dan Wisarja (2011:93126) dalam Teologi Sosial: Persoalan Agama dan Kemanusiaan Perspektif Hindu terdapat sub-bab yang membahas tentang kerusakan ozon akibat ulah manusia. Dalam buku ini terdapat contoh perhitungan untuk mengetahui berapa besar dosa yang dilakukan oleh setiap orang terhadap bumi. Melalui perhitungan yang dilakukan dapat diketahui bahwa semakin sejahtera atau kaya orang, maka makin besar dosanya yang dilakukan pada bumi. Mengapa demikian? Karena penggunaan fasilitas rumah mewah seperti; AC, mesin pemanas kamar mandi, kedaraan mewah dengan jumlah perjalanan dengan menggunakan kendaraan mewah, dsb., semua aktivitas penggunaan sarana mewah (energi dan gas yang dihasilkan) ternyata mengotori atmosfir yang akhirnya menyebabkan kerusakan ozon. Sehingga orang-orang kaya dengan fasilitas serba canggih dan gaya hidup mewah memiliki andil dosa jauh lebis besar daripada orang miskin. Karena itu adalah logis jika pemerintah harus mendapatkan pajak lebih besar dari orang-orang kaya; melalui hasil penerimaan pajak itu pemerintah memiliki biaya untuk melakukan perbaikan lingkungan dengan menyelenggarakan proyek penanaman pohon. Sehingga pohon-pohon hijau itu dapat mereduksi produksi gas polutan yang mencemari udara.

\section{II.4 Energi Gelombang Pikiran dan Efeknya terhadap Ozon Sakala dan Niskala}

Para ilmuwan eksakta Barat masih enggan untuk melakukan penelitian tentang pikiran dan jiwa sebab mereka memandang bahwa objek studi 
tersebut belum memiliki pendekatan saintifik yang valid. Mereka menganggap bahwa studi tentang pikiran dan jiwa mengandung spekulasi yang terlalu besar, sehingga mereka menganggap bahwa studi pikiran dan jiwa merupakan studi di luar dari bingkai penelitian ilmiah yang hasilnya dapat dilakukan uji klinis. Sebaliknya, para bijak Hindu ribuan tahun yang lalu melalui riset kontemplatik pada makrokosmos dan mikrokosmos telah berhasil membuat berbagai formulasi tentang pikiran dan jiwa. Kesimpulan para yogi, maharsi bijak menyatakan bahwa jiwa adalah realitas akhir yang mesti dicari dan direalisasikan oleh setiap orang. Melalui sadhana atau disiplin yang tinggi dengan pengendalian pikiran, maka jiwa akan dapat direalisasikan, itulah dimaksud dengan menemukan atau bertemu dengan Tuhan dalam diri oleh Rohit Mehta (2016:171) setelah memahami secara mapan tentang pengetahuan paravidya dan aparavidya. Uraian Rohit Mehta ini sesuai dengan uraian MundakaUpanisad.

\section{Maghsri (1995:1) dalam Bio Listrik Tubuh} Tenaga Dalam menguraikan bahwa: Baik agama, aliran mistik dan sistem filsafat yang dihasilkan intuisi supra-intelektual menyatakan bahwa manusia terdiri dari badan kasar dan badan halus. Keberadaan badan kasar telah diselidiki oleh ilmu fa'al sampai dengan atom-atomnya, sedangkan badan halus belum pernah diteliti oleh bidang eksakta. Melalui asumsi dan penalaran mendalam, sesungguhnya setelah struktur atom berhasil dipecah-pecah ke dalam beban listrik, maka timbulah kemungkinan bahwa dalam tubuh halus manusia juga dapat didekati dengan menggunaka kaidah-kaidah ilmu modern. Melalui pikiran yang kemudian ditingkatkan kea rah intuisi supraintelektual, manusia akan dapat menemukan hakikat badan halus. Sedangkan pikiran yang terikat kepada materi hanya menemukan wujud yang masih terselubung sebelum sampai pada realitas akhir. Saat ini selubung itu telah dapat diungkap sedikit demi sedikit dan telah ditemukan bahwa aliran materialism tidak lebih dari aliran yang dapat diibaratkan hak-hak yang kehilangan mainannya (naif). Aliran materialism telah dikategorikan sebagai barang kuno, tetapi masih layakuntuk dipertontonkan kepada khalayak ramai, dengan tujuan agar generasi berikutnya dapat menghargai buah pikiran para nenek moyangnya. Teori relativitas dan teori quantum serta mekanika gelombang mampu mengubah semua pandangan kita tentang isi alam semesta. Sinar rotgen, eletron, dan quantum merupakan pendapat-pendapat baru yang berusaha menyanggah pendapat para pendukung teori materialisme. Ada kemungkinan bahwa suatu saat kelak terjadi hubungan antara fisika dan metafisika sehingga "abad kedua puluh" ini menjadi saksi bagi terbukanya selubung rahasia hayati menyangkut keberadaan lahir dan batin manusia dengan cara rasional dan ilmiah.

Terkait dengan pikiran Maghsri (1995:10) menguraikan bahwa pikiran kita tersusun dari electron-elektron yang selalu bergerak dari satu tempat ke tempat lain melalui serat-serat saraf di dalam otak, lebih-lebih jika pikiran setiap detiknya selalu ditambah rangsangan baru berupa tangkapan panca indra. Jika kita mulai tafakur (samadhi), mati raga dengan jalan menutup Sembilan pintu dalam tubuh kita dan dengan keras kita menuntut kehidupan suci, sedangkan seluruh pikiran kita bebaskan dari semua keinginan dan kemarahan, serta kita pusatkan pikiran ke arah pusat pangkal segala yang ada atau asas pusat (Het Centrale Beginsel), maka pada suatu ketika kita akan memperoleh ketenangan, ketentraman dan rasa damai di batin kita, karena roh atau pikiran kita mencapai mutmainah (samadhi). Electron-elektron di dalam otak yang menyusun pikiran kita berhenti berputar kembali menjadi ether, dengan demikian maka lenyaplah semua electron yang menjadi pikiran termasuk pikiran itu sendiri, terutama pikiran yang mengandung tangkapan panca indera, yaitu pikiran yang berupa materi. Berubahnya electron-elektron menjadi ether, terlepas pulalah tenaga yang menggerakan electron-elektron, baik gerakan electron yang berputar maupun gerakan electron yang kian kemari. Tenaga yang dilepaskan ini diterima oleh otak sebagai sinar yang dinamakan sinar batin.

Ether bekas electron-elektron badan pikiran tadi lalu masuk ke dalam budi dengan menggunakan panca indera batin (sensus 
interior). Melalui panca indera batin, manusia dapat menyaksikan hakikat alam semesta secara langsung melalui peristiwa resonansi. Hakikat alam semesta ini adalah Intelek Pertama menurut Ibn'Al ArabiatauBrahman menurut Hindu. Pikiran pada mulanya terdiri dari electron-elektron sekarang menjadi pikiran yang terdiri dari butiranbutiran ether di dalam budi. Butir-butir ether ini bergetar dan getarannya dapat dirasakan. Daya elektromagnetik menyampaikannya dengan peranta-raan getaran yang juga membutuhkan zat pembawa. Sebagaimana daya elektromagnetik, zat pembawanya terdiri dari zat yang lebih halus daripada electron-elektron yang menjadi pangkal daya elektromagnetik itu sendiri, maka daya getaran ether juga harus memiliki zat pembawa yang lebih halus, yaitu zat mutlak. Gelombang zat mutlak itu sudah sepantasnya memiliki kecepatan lebih tinggi dari gelombang ether.

Selanjutnya Maghsri (1995:58) menguraikan tentang biolistrik, sesuai judul bukunya bahwa biolistrik adalah daya listrik hidup yang terdiri dari pancaran electron-elektron yang keluar dari setiap titik tubuh (disebut: titik energi) yang muncul karena adanya rangsangan penginderaan. Pikiran kita terdiri dari daya listrik hidup, semua daya ini berkumpul di dalam pusat akal otak dalam bentuk potensi daya listrik. Dari pusat akal, daya ini lalu dikerahkan diarahkan ke seluruh anggota tubuh yang kemudian bergerak oleh perangsang. Potensi daya listrik hidup ini yang tertimbun di dalam pusat akal harus dituntut (dipaksakan) oleh sesuatu agar mengalir untuk mengadakan gerakan tubuh kita atau bagian tubuh lainnya. Daya listrik ini harus terlebih dahulu melalui tumpukan otak dan masuk ke dalamnya. Tumpukan otak adalah pangkal nafsu-nafsu keinginan. Arus listrik hidup yang datang dari pusat panca indera di dalam tampuk otak melepaskan electron-elektron hidup yang dihasilkan oleh proses ulang (system of relays) yang berlangsung di dalam tumpuk otak, sehingga arus listrik hidup yang masuk ke dalam otak itu, selalu bercampur dengan daya listrik hidup yang berasal dari tumpukan otak. Itulah sebabnya, pikiran kita selalu bercampur dengan nafsu.
Lebih lanjut Maghsri (1995:74) mengu-raikan tentang hubungan pernafasan dan tenaga dalam, ia menyatakan bahwa dalam dunia kedokteran, peristiwa listrik dalam tubuh ini sudah dimanfaatkan antara lain untuk mendiagnosa gelombang listrik otak dengan EEG. Untuk dapat bertahan hidup manusia membutuhkan oksigen untuk bernafas, tentu saja bernafas biasa berbeda dengan bernafas untuk sehat dan mengembangkan potensi daya listrik hidup. Orang biasa menyebut tenaga dalam, bernafas biasa dikerjakan secara reflex, sedangkan bernafas untuk tujuan mencapai kualitas kesehatan dan pengembangan daya listrik hidup (bio-electric) dilaksanakan secara sadar dan teratur.

Demikianlah uraian Maghsri yang dipaparkan secara logis yang saintifik tentang pikiran hubungannya dengan bio-listrik atau listrik hidup yang memiliki efek positif baik bagi tubuh manusia sebagai mikrokosmos dan terhadap dunia sebagai makrokosmos. Uraian Maghsri ini menjadi landasan Ilmu Bela Diri Tenaga Dalam Satria Nusantara (SN), hal ini dipandang sebagai pengetahuan yang baru. Pada beribu-ribu tahun yang hal ini telah dijelaskan dan dipraktikan oleh para yogi Hindu. Saat ini salah satu Universitas Hindu Internasional di AS, yaitu Mahesyogi University di US telah mengembangkan yoga yang disebut Transcendental Meditation (TM). Pembelajarannya ini telah membuktikan bahwa yoga mampu membuat berbagai keajaiban, orang bodoh bisa menjadi supercedas, hal ini sudah dibuktika dan diterapkan pada SMA/SMK Bali Mandara (Donder, Majalah Media Hindu Edisi No.167: hlm. 8-23). Dalam banyak sumber dinyatakan bahwa yoga dapat membangkitkan kedadaran suprakosmis tetapi para fisikawan Barat masih setengah hati mengakuinya karena prosedur epistemology pengajaran membutuhkan waktu yang lama dan pengendalian diri yang mapan berbeda dengan epistemologi ilmu pengetahuan ilmiah positivistic yang hanya bersandar pada kebenaran panca indria dan sama sekali tidak pernah dihubungkan dengan spiritual atau pembahasan indra keenam.

Sesungguhnya sejak dahulu para ilmuwan fisika memiliki peluang untuk masuk ke dunia 
spiritual namun karena paradigm positivistic telah menentukan batasan sain atau ilmu pengetahuan yang hanya berdasarkan pada kebenaran panca indra, sehingga para ilmuwan fisika masih malumalu. Namun belakangan ini ketika Fritjof Capra seorang ahli fisika Kuantum menjelajah ilmu pengetahuan Timiur terutama India dan China, demikian juga Deepak Coopra serta para murid Maharsi Mahesyogi di Universitas Mahesyogi; selanjutnya hasil-hasilnya telah dipublikasikan ke seluruh penjuru dunia, maka para ahli fisika lainnya mulai merangka mencoba masuk melakukan penelitian-penelitian spiritual yang sebelumnya dianggap dunia yang gelap. Sikap para ilmuwan positivistic tersebut tidak salah, sebab mereka sudah terbiasa dan sangat percaya dengan ilmu positivistic karena ukuran kebenaran ilmiah positivistic itu dapat dibuktikan dengan segera. Sedangkan prosedur pengajaran dan praktik spiritual terlalu lama sehingga dianggap sebagai suatu yang subjektif.

Ilmu Fisika menjelaskan bahwa segala sesuatu memancarkan gelombang sinar, dan juga bervibrasi atau bergertar dan kemudian beresonansi, karena segala sesuatu memancarkan gelombang sinar, sehingga segala sesuatu dapat ditangkap oleh retina mata atau dapat dilihat oleh mata. Jadi, tidak terkecuali, seluruh unsur panca maha bhuta, yaitu akhasa (ether), vayu (udara), teja (api), apah (air) dan prthivi (tanah), semuanya memancarkan gelombang sinar dan bervibrasi. Demikian juga manusia, seluruh tubuhnya memancarkan gelombang sinar yang kerap juga disebut tenaga dalam, pancaran rohani, aura, pancaran spiritual, dsb. Vibrasi gelombang pikiran manusia memiliki efek kosmis. Donder (2007:386)

Saat ini gelombang astha prakrti alam semesta telah banyak dikacaukan oleh emisi gelombang pikiran manusia yang egoistik. Perut bumi atau prthivi yang mengandung unsur-unsur astha prakrti telah dieksploitasi secara besarbesaran dengan menggunakan energi ahamkara (ego), akhirnya sesekali bumi memberikan reaksi atau teguran melalui bencana alam. Hal ini sesuai dengan subhasita Sanskerta yang berbunyi: yad bhavam tab bhavati artinya: 'apapun yang dipikirkan (dikehendaki, dikerjakan) maka demikianlah jadinya'. Karena itu tepat juga jika dinyatakan bahwa segala kejadian alam ini merupakan refleksi dari perilaku umat manusia. Ebiet G. Ade menyatakan alam bosan bersahabat dengan kita. Jika tidak percaya dengan pernyataan Ebiet, maka Ebiet menyuruh menanyakan kebenaran itu kepada rumput yang bergoyang. Alasannya, karena pengakuan manusia saat ini sudah sangat jauh dari kejujuran. Vibrasi dari uap pikiran yang penuh dengan kebohongan dan kelicikan itu telah mengangkasa dan membentuk lapisan OZON EGO di atmosfir. Ozon egois tersebut telah merefleksi ke bumi sehingga dunia saat ini paling mudah mendapat pengaruh buruk daripada pengaruh baik. Kondisi seperti ini sangat sesuai dengan karakter kaliyuga yang memang cenderung manusia berotak kotor, egois, materialistis, dan raksasis.

Suja (dalam Donder, 2007:387) juga menyatakan bahwa sesungguhnya bencana alam itu diciptakan oleh energi ahamkara pikiran manusia. Pikiran sesungguhnya merupakan gelombang, sehingga ia tepat jika dikatakan sebagai "gelombang pikiran". Pikiran sebagai gelombang berinterferensi dengan gelombanggelombang lain yang memiliki frekuensi yang sama. Pikiran dapat mengetarkan pikiran orang lain. Sebagaimana gelombang sinar yang dapat bergerak hingga jutaan tahun sebelum menemukan pemantulannya, setiap gelombang pikiran yang keluar dari otak seseorang akan mengembara atau merambat kemana-mana sampai menemukan gelombang pikiran yang vibrasinya sama atau selaras, sehingga dapat menerimanya dengan penuh simapti. Sangat mungkin atmosfir tempat kita hidup saat ini dipenuhi oleh berbagai gelombang pikiran baik maupun buruk yang masing-masing mencari sasaran untuk penyelarasan dengannya. Di atmosfir terdapat gelombang pikiran jahat dari Rahwana, gelombang pikiran rakus Duryodana, gelombang pikiran licik Sakuni, gelombang pikiran kejam Hitler, dan lain-lain. Di atmosfir ini juga merambat gelombang pikiran yang penuh kasih dari; Budha, 
Kristus, Gandhi, Theresia, Sathya Narayana (Bhagavan Sri Sathya Sai Baba), dll. Juga gelombang pikiran yang penuh kebijaksanaan dari Krishna. Gelombang pikiran yang berwujud kebenaran dari Rama, Janaka, Yudhistira, dan lain-lain. Selain itu, gelombang pikiran yang penuh dengan pengabdian dari Prahlada, Anoman, Arjuna, Drupadi, dll. Itulah beberapa gelombang senantiasa merambat di sekitar kita bersama-sama gelombang lainnya yang secara aktif dipancarkan dari sumber emisinya.

Lebih lanjut Suja(dalam Donder, 2007:387) menguraikan bahwapararel dengan perubahan alam semesta menuju kepada "kesemerawutan yang semakin meningkat", dan sementara ruang atmosfir tetap terbatas, dan setiap saat diemisikan gelombang informasi ke atmosfir, maka lingkungan kita akan semakin pekat dengan gelombang, sampai akhirnya akan mencapai derajat kejenuhan. Dalam kondisi seperti itu maka semakin sulitlah bagi kita untuk menenangkan pikiran, karena senantiasa ada interferensi dari luar. Dalam hidup bermasyarakat, setiap saat panca indria dirangsang oleh gelombang-gelombang yang dapat meningkatkan nafsu hewani manusia, baik secara fisik maupun bentuk gambar, bayangan, suara dan lain-lain. Interaksi dapat terjadi apabila ada frekuensi yang sama dalam pikiran kita. Getaran gelombang yang semakin semerawut membuat manusia alpa dengan nilainilai kemanusiaannya; dan inilah yang semarak terjadi dewasa ini. Orang-orang gandrung mencari sumber yang dapat membuat pikirannya tersiksa. Entah berapa uang dan waktu telah dihabiskan, hanya untuk kebutuhan gelombang yang dapat menyemerawutkan pikiran. Inilah eronisnya, manusia justeru merasa senang setelah gelombang pikirannya diacak oleh sumber gelombang dari luar. Gelombang suara yang menyayat hati lewat speaker tabung ajaib itu, menjadikan pikirannya semakin galau. Dalam kehidupan sehari-hari, kita juga sangat banyak menemukan orang-orang yang mengemisikan gelombang pikiran yang sangat tidak teratur. Orang-orang seperti ini perlu diwaspai dalam mengajaknya bergaul, sebab vibrasi gelombang pikiran dan vibrasi gelombang suara orang-orang tersebut sangat berpengaruh terhadap gelombang pikiran kita.

Lebih lanjut Suja (dalam Donder, 2007:388) menguraikan bahwa agar manusia dapat membebaskan diri dari gelombang-gelombang informasi yang menyesatkan, setiap orang seharusnya rajin menyelaraskan gelombang pikirannya dengan sumber gelombang kesucian, sumber gelombang kebijaksanaan, sumber gelombang kebenaran, dan itulah Tuhan. Gelombang spiritual itu berlimpah adanya dan tidak memerlukan modal untuk mendapatkannya.
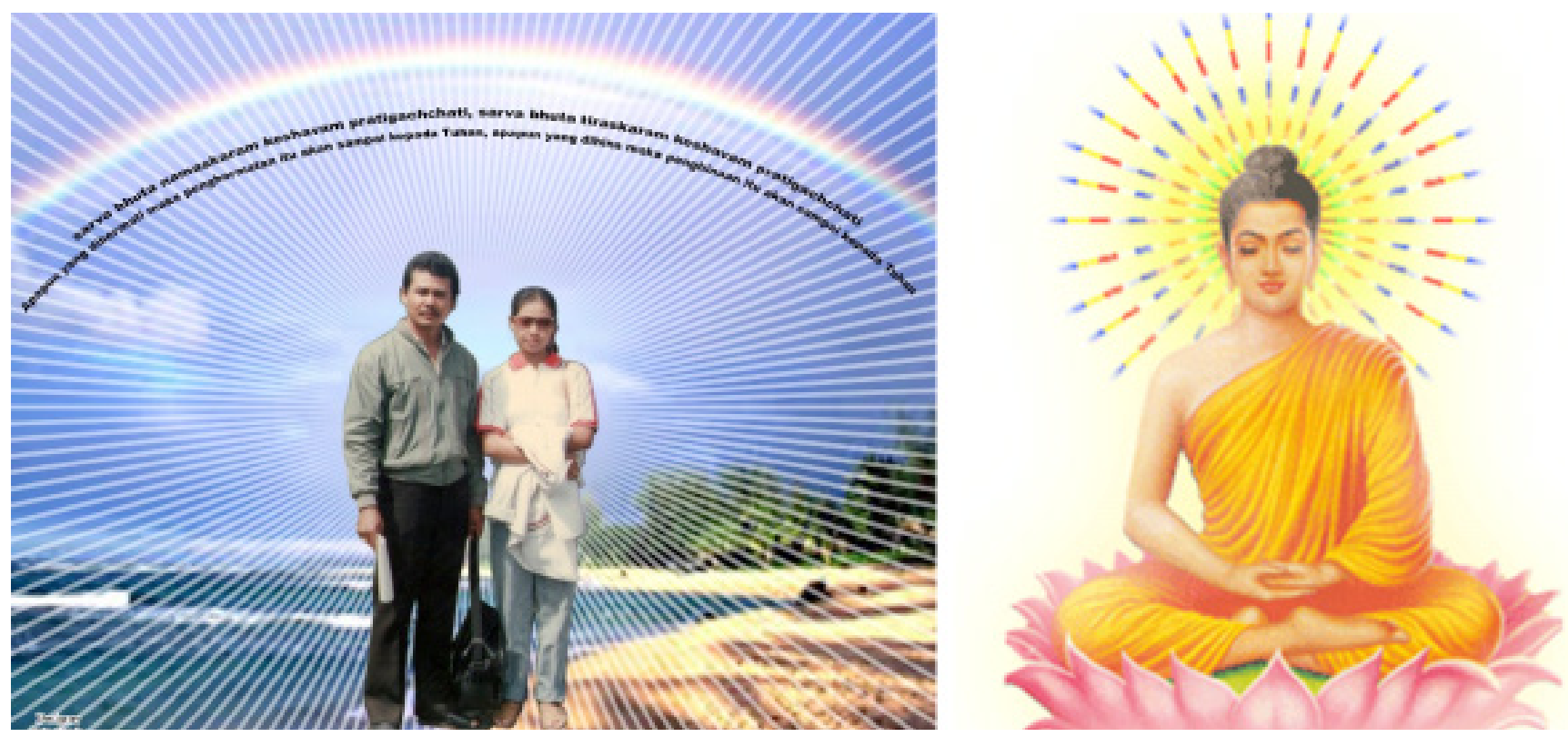

Gbr. Ilustrasi Vibrasi Alam Semesta dan Vibrasi Pikiran Manusia 


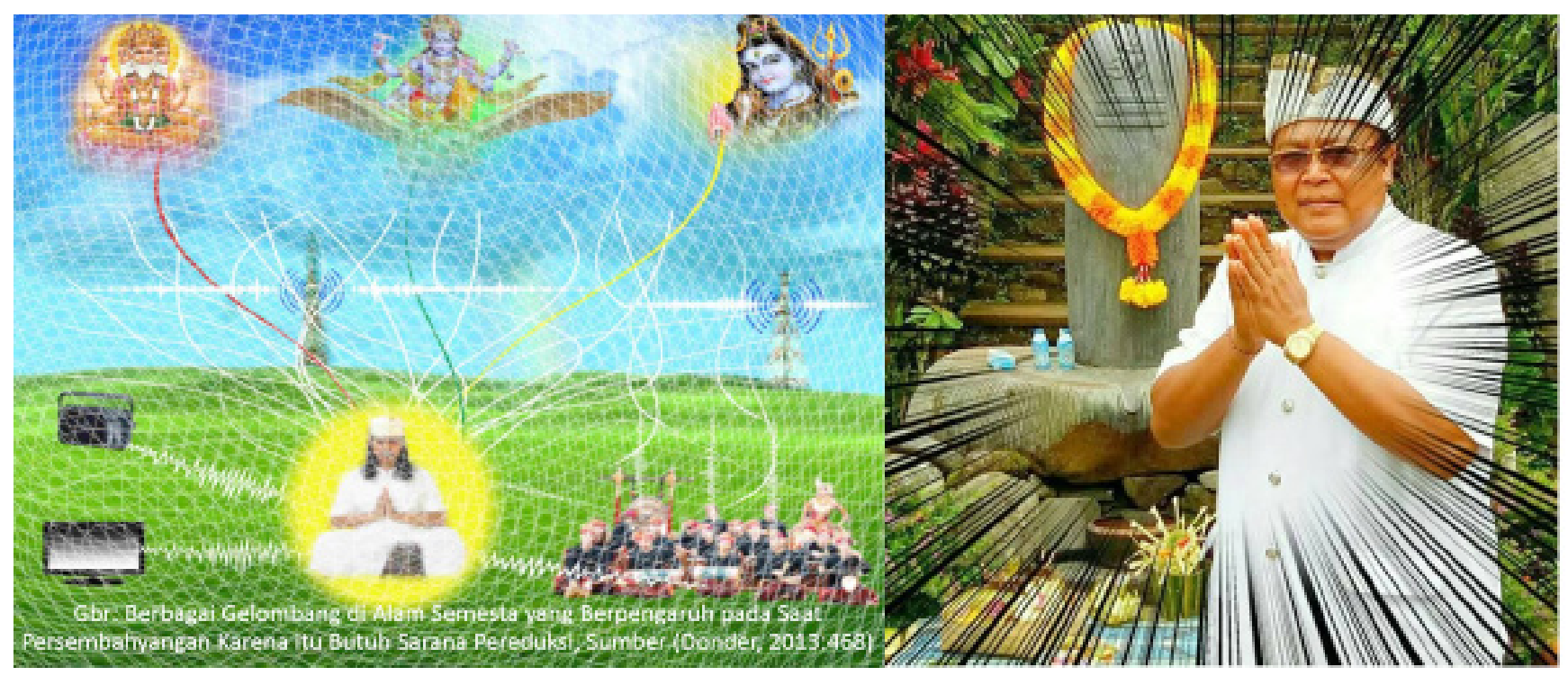

Gbr. Foto Ilustrasi Hambatan Konsetrasi akibat Polusi Gelombang Kosmis

Sembahyang, berdoa, kirthanam (memuji namanama Tuhan), japa, merupakan wujud upaya untuk membebaskan diri dari polusi (pencemaran) gelombang negatif di alam semesta ini. Jika upaya itu telah berhasil membawa frekuensi pikiran manusia pada level frekuensi yang sama atau selaras dengan level frekuensi alam semesta, maka vibrasi tersebut akan menjadi sarana interferensi terhadap frekuensi vibrasi gelombang Tuhan, dan itu membuat manusia dekat dengan Tuhan (Suja dalam Donder, 2007;388).

Mengetahui bahwa pikiran manusia ikut memberi andil terhadap kerusakan lapisan ozon, maka seyogyanyanya manusia yang disebut sebagai mahluk paling mulia, yang setiap harinya makin cerdas, makin intelek, makin memiliki pengetahuan yang luas, berpikir dan bertindak semakin akademis, mestinya turut berupaya mendapatkan pencerahan, mengalami pencerahan dan memberikan pencerahan tentang pentingnya berpikir positif. Sebagaimana Bhagavadgita menyatakan: "segala kebiasaan dari orang besar akan diikuti masyarakat lainnya (Bhagavadgira III.21); mereka yang intelek atau bijaksana jangan membingungkan masyarakat awam (Bhagavadgita III.26).

Jika para tokoh masyarakat, tokoh rohaniawan, intelektual, tokohPendidikan, dan para tokoh politik otaknya kotor, maka atmosfir bumi pasti juga akan kotor, maka hal itu akan menjadi mind set mikrokosmos yang akan berhubungan dengan mind set bumi atau makrokosmos dalam wujud lapisan ozon. Hubungan ozon mind set manusia yang mengotori ozon mind set bumi akan menimbulkan anomaly dan chaos atau ketidakpastian dan ketidak-teraruran. Jika lapisan ozon mind set manusia dan ozon main set bumi tidak selaras atau tidak harmonis, maka energi mantramyang dikumandangkan oleh seorang yang dianggap memiliki kualitas kesucian sekalipun tidak akan serta mampu melewati kesemerawutan gelombang di atmosfir bumi yang kotor oleh mind setmanusia yang penuh dengan pikiran kotor sebagaimana diilustrasikan pada gambar dalam disertasi Donder (2013:468).

\section{II.5 Dosa Nyata Manusia atas Alam dan Reak- si Alam terhadap Dosa Manusia}

Membahas tentang dosa manusia atas alam semesta dan reaksi alam terhadap dosadosa manusia masih susah dipahami oleh banyak orang termasuk oleh para intelektual eksakta. Para intelektual eksakta menganggap itu hanya sebagai suatu kepercayaan dogmatis yang tidak dapat dijelaskan secara ilmiah. Anggapan para intelektual dalam sain itu tidak salah, karena mereka tidak memahaminya, yang disebabkan oleh para intelektual agama (Hindu) tidak mampu mengilmiah ajaran agama (Hindu). Sebagian besar para intelektual Hindu stagnan pada aporisma Brahma Sutra I.1.3 yang menyatakan bahwa satu- 
satunya cara yang paling baik dana tau paling tepat untuk memahami Tuhan adalah pustaka suci. Mereka hampir tidak pernah membaca ajaran Maharsi Vasista sebagaiman dikutip oleh Radhakrishnan (2010:133)dan telah dikutip di atas. Vasista dengan tegas memerintahkan agar manusia menggunakan nalar atau kecerdasan dalam meyakini dan mempertahankan ajaran agama. Selain factor-faktor di atas, secara umum memang para intelektual Hindu belum terlalu konsen untuk meneliti agama karena kekurangluasan wawasan keilmuannya yang seharusnyakajian tentang Hindu harus menggunakan pendekatan mulitidisilpner atau interdisipliner, sebab pengetahuan Hindu secara utuh meliputi pengetahuan paravidya dan pengetahuan aparavidya. Sebagian besar para intelektual Hindu belum memahami prosedur epistemology paravidya dan aparavidya. Ketidakpahaman mereka memahami epistemology kedua bangunan pengetahuan tersebut membuat mereka ragu terhadap pengetahuan Hindu

Dosa manusia atas alam semesta dan reaksi alam atas perilaku manusia masuk dalam wilayah pengetahuan paravidya dan aparavidya. Mehta (2016:171) menguraikan bahwa paravidya itu sesungguhnya merupakan pengetahuan rahasia, pengetahuan yang gerakannya mengarah ke dalam diri manusia (mikrokosmos), dapat dinyatakan sebagai pengetahuan esoteris yang kebenarannya bersifat universal; sebaliknya aparavidya adalah pengetahuan yang mengarahkan penyelidikannya ke luar diri yaitu kepada alam semesta (makrokosmos), dapat dinyatakan sebagai pengetahuan eksoteris yang kebenarannya parsial. Para intelektual Hindu tidak boleh mempertentangkan kedua pengetahuan tersebut agar mampu melihat dan mendengar serta memahami alam semesra beserta seluruh isinya secara holistik

Lebih lanjut Mehta menguraikan bahwa walaupun sering dinamakan pengetahuan rahasia tetapi sebenarnya tidak dirahasiakan oleh manusia. Memang agak janggal, karena rahasia itu berada di alam terbuka, terpampang untuk dilihat oleh siapa saja. Pengetahuan itu selalu di sana disaksikan oleh setiap orang, tetapi orang itu sendiri tidak melihatnya, karena itu seperti diselubungi oleh tabir dan tidak melihat kesejatian yang berada di depan matanya. Kebutaan itu bukan cacat mata organik. Sesungguhnya, tidak ada orang yang
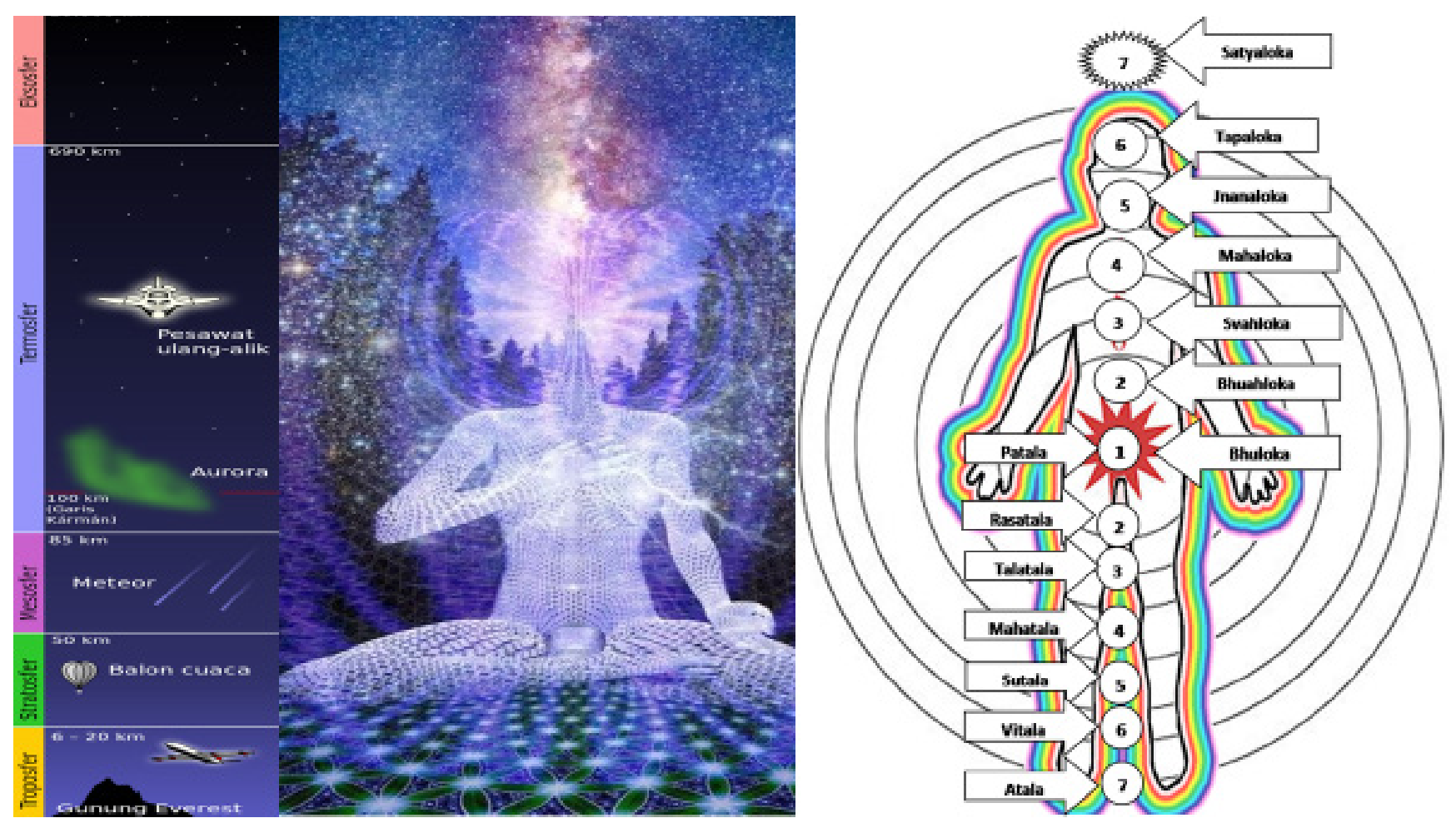

Gbr. Ilustrasi Pikiran Manusia Menembus Seluruh Lapisan Atmosfir Juga menembus alam Sapta Loka dan Sapta Tala 
lebih buta daripada orang yang tidak mau melihat. Kebutaan umat manusia bersifat demikian ini. Sebenarnya tidak ada seorangpun yang dapat merahasiakan pengetahuan eksoteris ini dari penglihatan orang lain. Orang yang tidak melihat pengetahuan eksoterik itu, sesungguhnya sedang menutupi matanya sendiri, berpaling menjauh dari sinar terang, kemudian berteriak mengatakan di lingkungannya itu terlalu gelap.Pengetahuan eksoteris adalah pengetahuan tentang Sang Pencipta yang bersembunyi di balik ciptaan-Nya itu. Inilah maksud kalimat yang menyatakan bahwa Brahman: "bermukim di dalam guha (hati kecil) nurani manusia". Sepintaslalu Brahman (Tuhan) itu rahasia, tetapi orang yang mau berpikir dan merenungkan kedalaman persepsinya akan melihat Sang Pencipta itu bersatu dengan mahlukmahluk yang diciptakannya, bersembunyi dalam hati sanubari.

Mehta (2016:171) lebih lanjut menyatakan bahwa: "Dia yang memancarkan sinar cemerlang, yang lebih halus daripada yang terhalus, dengan mana seluruh alam dan seluruh mahluk di dalamnya ditunjang kehidupannya, Dia itulah Brahman yang tidak termusnahkan. Itu saja yang perlu dicari, carilah itu. Jadikan Brahman sebagai sebagai sasaran, sebagai tujuan akhir pencarian itu. Demikianlah uraian Mehta yang sangat penting yang meyakinkan bahwa manusia dapat mencari dan menemukan Tuhan di sini, di dalam ciptaanNya.Untuk memahami kedua macam pengetahuan ini sangat penting merujuk buku karya Gauri Sangkar Gupta (2012) yang berjudul Unraveling Mysteries of Life - Modern Science and Ancient Wisdom. Bagian yang terpenting dalam karya Gupta ini

Do the modern scientific discoveries provide better answers to the basic issues of existence such as origin and functioning of the universe, evolution of life, interaction between human civilization and nature, the purpose of human life, human development and human happiness? Are these unprecedented innovations and discoveries and large scale production technologies leading to human well-being and happiness or are they merely creating an illusion of happiness?

This book attempts to address some of these fundamental questions through comparative study of the discoveries of modern science and the wisdom of ancient writings left behind by our ancestors. Widely accepted contemporary scientific theories, discoveries and inventions addressing fundamental issues of life and existence constitute the basis of modern scientific explanations. The Vedic and some ancient Greek writings constitute the core of ancient wisdom expounding on these basic issues. The Upanishads, the Bhagvad Gita, the BrahmanSutra, the Srimad Bhagavatam and the Mahabharata constitute the primary source of ancient Indian wisdom. Relevant writings of pre-Socratic times and those of Plato, Aristotle and Plotinus constitute the primary source of ancient wisdom from Greece.

Based on the comparative study of the two, an attempt has been made to address some of the mysteries of creation and the purpose of human life. Following the comparative study of the two, the book brings out the relevance and richness of the ancient wisdom. Although modern science and new technologies have transformed human life beyond recognition through spectacular material comforts, these have failed to address the basic questions of life and existence. Human happiness remains elusive despite these material comforts and scientific advances. Humanity is getting lost into details forgetting the fundamentals. The question whether the ancient wisdom is based on scientific discoveries or is merely philosophical in nature has also been analyzed in a step by step approach (Gupta, 2012:13).

'Buku ini berupaya menjawab beberapa pertanyaan mendasar melalui suatu studi banding antara penemuan sain modern dan kebijaksanaan kuno yangditulis dan 
kemudian diwariskan oleh nenek moyang kita. Diterimanya secara luas teori ilmiah kontemporer atas penemuan isu-isu dasar kehidupan dan eksistensi merupakan dasar dari penjelasan ilmiah modern. Veda dan beberapa literature Yunani Kuno merupakan inti kebijaksanaan kuno yang menguraikan tentang isu-isu mendasar ini. Upanisad, Bhagavadgita, Brahma Sutra, Srimad Bhagavatam dan Mahabharata merupakan sumber utama kebijaksanaan India kuno. Sebaliknya, tulisan-tulisan yang relevan dari zaman pra-Socrates dan juga tokoh-tokoh besar seperti Plato, Aristoteles dan Plotinus merupakan sumber utama kebijaksanaan kuno dari Yunani.

Berdasarkan studi perbandingan atas keduanya (India dan Yunani), berbagai upaya telah dilakukan untuk mengurai beberapa misteri penciptaan dantujuan hidup manusia. Melalui studi banding dari keduanya, akhirnya buku ini menyajikan tentang relevansi dan kekayaan kebijaksanaan kuno. Meskipun ilmu pengetahuan modern dan teknologi baru telah mengubah kehidupan manusia melalui kenyamanan materi yang spektakuler, namun ia telah gagal menjawab pertanyaan-pertanyaan tentang dasar kehidupan dan eksistensi. Kebahagiaan manusia tetap sulit dipahami meskipun berada dalam kenyamanan materi dan kemajuan ilmiah (yang telah diterapkan pada saat) ini. Manusia tersesat karena melupakan hal yang sangat fundamental. Pertanyaan apakah kebijaksanaan kuno didasarkan pada penemuan-penemuan ilmiah atau hanya sekedar filosofis alam juga telah dianalisis setahap demi setahap. Masalah mendasar yang dibahas dalam buku ini mencakup asal-usul alam semesta, misteri alam semesta, penciptaan/evolusi kehidupan, kesehatan manusia, permainan kehidupan manusia, misi kehidupan, makna pembangunan dan kebahagiaan manusia'.

Membaca prolog atau pengantar buku Gauri tersebut di atas dapat disimpulkan bahwa ilmu pengetahuan ilmiah (sain) dan teknologi canggih yang telah dipergunakan sebagai sarana atau fasilitas dalam menikmati kenyamanan hidup umat manusia, namun belum cukup untuk mencapai puncak pencarian manusia. Sain dan teknologi canggih yang telah dikuasai manusia belum mampu membantu manusia untuk mencapai realisasi Diri dan belum mampu mengungkap esensi Tunggal yang ada di balik semua ciptaan ini. Karena itu, sudah sepantasnya manusia mengupayakan pengetahuan paravidya dan aparavidya secara bersamaan sebagai kebutuhan di dunia dan mencapai puncak realisasi Diri.

\section{KESIMPULAN}

Beradasarkan pembahasan judul tentang vibrasi pikiran, kerusakan ozon, dan bencana alam satu kesatuan system kesadaran kosmos suatu kajian perspektif teokosmologi post metafisika dengan sub-sub bab pembahasan, yaitu: $1.1 \mathrm{Veda}$ Pengetahuan Mahaluas Menginspirasi Para Ilmuwan; 1.2Teori Vedantatentang Penciptaan; 2.1 Teori Penciptaan Jagadraya sebagai Sebuah Sistem Semesta; 2.2 Fisika-Metafisika, SakalaNiskala, Kesadaran Kosmos dan Fisika Spiritual; 2.3Ozon Gas Beracun Pelindung Kehidupan di Bumi dan Dosa Manusia atas Bumi; 2.4Energi Gelombang Pikiran dan Efeknya terhadap Ozon Sakala dan Niskala; 2.5Dosa Nyata Manusia atas Alam dan Reaksi Alam terhadap Dosa Manusia, maka dapat disimpulkan bahwa:

1. Vedamerupakan wahyu Tuhan berisi pengetahuan mahaluas, berisi tentag segala gagasan pengetahuan yangmeliputi pengetahuan paravidya (spiritual, metafisika) dan pengetahuan aparavidya (sain dan teknologi). Pengetahuan mahaluas itu diterima oleh para maharsi zaman dahulu kala melalui riset (pencarian) secara sungguh-sungguh dengan metode kontemplasi; hingga frekuensi gelombang pikirannya selaras dengan frekuensi gelombang jagadraya sebagai tirai pembatas antara manusia dan Tuhan. Keselarasan frekuensi pikiran para maharsi tersebut mampu menguak tirai jagaraya yang di dalamnya Tuhan bersembunyi; melalui itusehingga wajah Tuhan yang ada dalam 
manifestasi-Nya menampakkan diri sebagai para dewa penguasa berbagai segmensegmenkosmos. Pengetahuan Vedayang luas itu menginspirasi para ilmuwan dalam rangka mengkonstruk berbagai ilmu pengetahuan. Semua ilmu pengetahuan yang pernah ada, yang sedang ada dan yang akan ada berasal dari Veda.

2. Teori Vedantaberkenaan dengan penciptaan menguraikan bahwa ciptaan ini hanyalah mainan Tuhan yang diciptaan dari diri-Nya sendiri.Pencipta dan ciptaan-Nya adalah satu kesatuan seperti benda dan bayangannya, seperti generator listrik dan alirannya. Oleh sebab itu, memuji atau menghina ciptaan sesungguhnya sama dengan memuji atau menghina Tuhan, karena sumber asalnya adal Tuhan.

3. Teori penciptaan jagadraya merupakan sebuah sistem semesta; hal itu berarti bahwa segala sesuatu berada dalam jarring-jaring system seperti net pada permainan bola volley. Jika setiap ciptaan diumpamakan sebagai satu simpul yang pada net permainan bola volley, maka goncangan salah satu simpul akan menyebabkan goncangan pada seluruh simpul net. Itu artinya, setiap segmen alam yang mengalami disharmonisasi, maka disharmonisasi itu akan berpengaruh pada seluruh system semesta.

4. Realitas fisik, metafisik atau sakala-niskala, kesadaran, kosmos dan fisika spiritual merupakan satu kesatuan pengetahuan paravidya dan aparavidyaberfungsi secara aksiologis untuk membantu umat manusia mencapai realisasi Diri.

5. Ozon satu lapisan pelindung bumi yang sesungguhnya merupakan gas beracun yang berada di wilayah atmosfir bumi menjadi lapisan pelindung bagi kehidupan seluruh mahluk di bumi. Lapisan ozon saat ini sudah banyak rusak disebabkan oleh sikap dan perilaku umat manusia yang tidak peduli dengan kesehatan lingkungan karena tidak memahami esensi ozon sebagai unsur mahapenting yang pelindung kehidupan semua mahluk di bumi. Kerusakan ozon lebih banyak disebabkan oleh gaya hidup manusia, semakin canggih peralatan yang digunakan, peralatan yang menggunakan tenaga listrik atau bahan bakar minyak, akan berdampak semakin besar terhadap kerusakan ozon dan berisika sangat fatal terhadap kehidupan di bumi. Hal itu merupaka dosa yang sangat nyata pada seluruh mahluk yang ada di atas bumi.

6. Gelombang energi pikiran memiliki efekterhadap kerusakan ozon baik ozon dalam artian material (sakala) dan ozon dalam artian spiritual (niskala). Secara material pikiran manusia yang egois, vibrasi gelombangnya akan merambat atau mengembara ke seluruh penjuru dunia kemudian akan mempengaruhi pikiran lainnya. Secara spiritual ozon adalah wilayah akasha tempat para dewa-dewi memproduksi zat-zat yang bergunaka bagi kehidupan mahluk di bumi.

7. Umat manusia sangat penting memahami konsep advaita atau konsep kesatuan dengan segala hal di alam semesta ini. Konsep kesatuan semesta itu akan melahirkan sikap arif terhadap seluruh ciptaan sebagai manifestasi Tuhan. Menghormati seluruh ciptaan harus dipandang sebagai menghormati Tuhan, sebaliknya menghina apalagi merusak alam juga harus dipandang sebagai merusak tubuh Tuhan. Manusia harus memahami hukum aksi-reaksi yang berarti segala sesuatu adalah refleksi atas perilaku manusia.

\section{DAFTAR PUSTAKA}

Donder, I Keutu, 2007. Viratvidyā - Kosmologi Hindu: Penciptaan, Pemeliharaan, dan Peleburan Serta Penciptaan Kembali Alam Semesta, Surabaya: Paramita

Donder, I Ketut, 2009. Meditasi Bio-Energi Ratu Bagus - Meditasi Tarian Jiwa, Spiritual Holistik, dan Pembangkit Kesadaran Kosmis, Surabaya: Paramita

Donder, I Ketut dan I Ketut Wisarja, 2011. Teologi Sosial - Persoalan Agama dan Kemanusiaan Perspektif Hindu, Surabaya: Paramita 
Donder, I Ketut, 2014. Kebenaran Sejarah Agama Hindu - Upaya Meluruskan Sejarah (terj.), Surabaya: Paramita

Donder, I Ketut, 2018. "Upaya Gubernur Bali di Bidang Pendidikan Patut Dihargai”, Jakarta: Majalah MEDIA HINDU

Efferin, Roy Budi, 2006. Sains \& Spiritualitas - Dari Nalar Fisika Hingga Bahasa Para Dewa, Jakarta: One Earth Media

Maghsri, Syaiful M., 1995. Biolistri Tubuh Tenaga Dalam, Yogyakarta: Yayasan Satria Nusantara

Mehta, Rohit, 2016. Panggilan Upanisad Bertemu Tuhan Dalam Diri (alih bhs. Prof. Tjok. Rai Sudharta, Denpasar: Sarad

Titib, I Made, 2006. Penciptaan Jagatraya Menurut Hindu dan Tanggapan Terhadap Teori-teori Ilmiah Baru (karya kompilasi dalam Ilmu, Etika, dan Agama), Yogyakarta: Program Studi dan Lintas Budaya Pascasarjana UGM

Pudja, Gde dan Tjok. Rai Sudartha, 2004. Manava Dharmasastra, Surabaya: Paramita

Radhakrishnan, 2010. The Principla Upanișad, New Delhi: HiperCollin Publisher

Radhakrishnan, 2008. Upanisad-Upanisad Utama, Surabaya : Yayasan Parijata

Ridley, Mark, 1991. Masalah-Masalah Evolusi, Jakarta : Universitas Indonesia Press

Sagan, Carlk, 2000. Kosmologi, Jakarta : Yayasan Obor Indonesia

Saraswati, Prakashananda, 2004. The True History and the Religion of India, New Delhi: Rajiv Beri for Macmillan India Ltd.

Schuon, Frithjof, 2002. Transfigurasi Manusia: Refleksi Antrosophia Perinnialis, Yogyakarta : Qalam

Singh, J., 1998. Biopsychology : A New Science of Body, Mind, and Soul, Anandanagar : Ananda Mudranalaya

Sivananda, Sri Svami, 1998. Japa Yoga, Surabaya : Paramita
Sivananda, Sri Svami, 2003. Intisari Ajaran Hindu, Surabaya : Paramita

Sivananda, Sri Svami, 2005. Pikiran: Misteri dan Penaklukannya, Surabaya: Paramita

Gupta, Gauri Shankar, 2012. Unraveling Mysteries of LifeIModern Science and AncientWisdom, E-book version: Csaba Varga 